DOI: $10.2478 / \mathrm{v} 10014-010-0016-\mathrm{y}$

Agrovoc descriptors: rotational cropping,plant protection,conventional tillage,traditional uses,integrated plant production, animal production,plant production,mixed farming,farming systems,monoculture,cropping systems, legislation,sustainability

Agris category code: F07, H01, L01

\title{
Crop rotation on arable and livestock farms in Slovenia
}

\author{
Darja KOCJAN AČKO ${ }^{1}$, Igor ŠANTAVEC ${ }^{2}$
}

Received Januar 19, 2010; accepted August 20, 2010.

Delo je prispelo 19. januarja 2010; 20. avgust 2010.

\begin{abstract}
Despite the fact that successive sowing of maize was legally limited due to the occurrence of the corn rootworm beetle in 2003 and the integrated crop production was introduced in 2004, maize is still the most common and desired crop on arable and livestock farms in Slovenia. With a focus on the economic motives for the production farmers are gradually beginning to consider also the phytosanitary viewpoint, but the planning of a crop rotation is a demanding task, especially for younger farmers with no previous experience. The results of the analysis of crop rotations on conventional and integrated arable and livestock farms in north-east and western Slovenia in the period from 2000 to 2009 show that the maize monoculture has been supplemented by other grains, mostly wheat and barley, but legumes and supplementary crops are still missing from the rotation. With newly introduced crops to Slovene fields the need for new and modern agro-technical measures is increasing and also the need for improved knowledge of biological characteristics of individual varieties and species with their suitable order and share in the crop rotation. To help the farmers find the best solution for their production we have prepared some recommendations for the crop rotations with the main and supplementary crops, following good and proven examples of crop rotations used in the past. Whether farmers will use them on their farms depends not only on their technical equipment and knowledge, flexibility and receptiveness, but also on the legislative measures and sustainable nature of EU agricultural policy where farmers got used to be paid for every function and production that is environmentally and food friendly.
\end{abstract}

Key words: crop rotation, phytosanitary importance of rotation, conventional crop production, integrated crop production, arable and livestock farms, Slovenia

\section{IZVLEČEK}

\section{KOLOBAR NA POLJEDELSKO-ŽIVINOREJSKIH KMETIJAH V SLOVENIJI}

V Sloveniji je koruza, kljub zakonski omejitvi zaporedne setve zaradi pojava koruznega hrošča leta 2003 in vključevanja kmetij v integrirano pridelavo poljščin leta 2004, še vedno najbolj razširjena in zaželena poljščina na poljedelskoživinorejskih kmetijah. Ekonomski vidik pridelave postopoma upošteva fitosanitarnega. Načrtovanje kolobarja je zahtevno, zlasti za mlajše kmete, ki nimajo izkušenj iz preteklosti. Rezultati analize kolobarjev na konvencionalnih in integriranih poljedelsko-živinorejskih kmetijah v severovzhodni in v zahodni Sloveniji v obdobju od leta 2000 do 2009 kažejo, da so monokulturo koruze razbremenila druga žita, zlasti pšenica in ječmen, manjkajo pa stročnice in dosevki. Z novo vključenimi poljščinami se povečujejo potrebe ne le po novi in sodobni agrotehniki, ampak tudi po poznavanju bioloških zakonitosti posameznih vrst in sort ob hkratni primerni razporeditvi in deležu v kolobarju. V oporo kmetom smo sestavili nekaj biološko uravnoteženih kolobarjev iz glavnih posevkov in dosevkov, ki se zgledujejo po preizkušenih vrstilnih kolobarjih iz preteklosti. Njihova uporaba na kmetijah bo odvisna ne le od tehnične opremljenosti kmetije, znanja, dojemljivosti in prožnosti gospodarjev ampak $\mathrm{v}$ glavnem od zakonskih predpisov in sonaravnih usmeritev kmetijske politike $\mathrm{v}$ EU, kjer so se kmetje navadili na plačilo za vsako okolju in hrani prijaznejše opravilo in postopek pridelave.

Ključne besede: kolobar, koruza, fitosanitarni pomen kolobarja, konvencionalna pridelava poljščin, integrirana pridelava poljščin, poljedelsko-živinorejske kmetije, Slovenija

\footnotetext{
1 Dr., Doc., Biotechnical Faculty, Dept. of Agronomy, Jamnikarjeva 101, SI-1111 Ljubljana, Slovenia, e-mail: darja.kocjan@bf.uni-lj.si

2 Dr., Assistant, Biotechnical Faculty, Dept. of Agronomy, Jamnikarjeva 101, SI-1111 Ljubljana, Slovenia, igor.santavec@bf.uni-lj.si
} 


\section{INTRODUCTION}

Balanced crop rotation with alternations between grains and non-grain cultures was designed in the middle of the $18^{\text {th }}$ century in Great Britain (Spanring 1959, Sadar 1961, Geisler 1980, Butorac 1999, Kocjan Ačko et al. 2005, Diepenbrock et al. 2005, Martin et al. 2006). Results of the scientific research and farmers experiences show that biologically balanced crop rotation can be achieved when 40 to 50 -percent of the fields are covered with grains, while root crops and legumes cover from 20 to $30 \%$ of land each. Especially legumes are very useful to maintain soil fertility (symbiosis with Rhizobium bacteria), and their phytosanitary importance within the crop rotation is reflected in reduced weediness, less infections and less damage on grains and root crops.

Approximately 40-percent share of maize in the sowing structure of crops in the last two decades puts Slovenia to the first place among all European countries (Tajnšek and Šantavec 1998; Statistical yearbook and Statistical information 2009). This wide use of maize in the rotation prevents the composition of a biologically balanced crop rotation. When maize is sown as a monoculture or in a narrow crop rotation (maize wheat/barley) we can find a higher occurrence of specific pathogens (fusariozis, corn smut - Ustilago maydis), pests (Elateridae, corn borer) and more weeds (Zscheischler et al. 1990, Čergan et al. 2008, Vogelsang et al, 2009).

We have studied the changes in the sowing structure of crops on arable and livestock farms. We analysed the composition of the crop rotation in first two regions that recorded the occurrence of maize beetle in Slovenia, where they had to - due to the legal provisions introduce maize into the crop rotation. We were also interested in differences in the composition of the rotation between conventional and integrated farms. The goal of the research was to prepare recommendations of biologically balanced crop rotations that could be used on arable and livestock farms in the future.

\section{MATERIALS AND METHODS}

The sequence of crops was studied on ten conventional and ten integrated farms in Pomurje (north-eastern Slovenia) and in Goriška region (western part of Slovenia) in the period from 2000-2009. We have recorded the crops in the rotation on individual farms where we also discussed with the householders the characteristics of the crop rotation and the sequence of the crops in the rotation.

Crop rotations were evaluated with the methods of analysis, synthesis, generalization and specialization referring also to domestic and foreign realizations, principles of the crop order in the rotation, duration of the rotation and results of the research. For each individual farm we determined the most frequent rotation of five crop rotations. We have analysed its composition before and after the appearance of the corn beetle in 2003.

We have reviewed the prohibitions, required measures and recommendations regarding the inclusion of the maize in the crop rotation. All producers have the obligation to respect the provisions of the Rules of the phytosanitary measures to prevent the spreading of the corn rootworm beetle (O.J. RS, no. 21/2004 and 106/2006) and Instructions of the Monitoring and Forecast Service on movement and occurrence of beetles that are posted on the internet (http://www.furs.si/ Diabrotica/Index.asp) and are simultaneously amended. Producers who decided on integrated production have to respect all prohibitions, demands and recommendations that are written in Technological guidelines for integrated crop production in the current year considering every change in situations. One of important required measures is five-year crop rotation where maize can be sown on the same land twice in three years, but never twice successively.

Following the example of the Norfolk crop rotation from the 18th century (Geisler 1980, Butorac 1999, Diepenbrock et al. 2005, Martin et al. 2006 ) and by composing four-year crop rotations and other modifications of the sequential crop rotation including the old Slovene five-year crop rotation (Sadar 1961) and the five-year Rhine crop rotation, used in Germany (Diepenbrock et al. 2005) we have prepared recommendations for new crop rotations considering also biological characteristics of individual species with the indication of their suitable share in the rotation.

\section{RESULTS AND DISCUSSION}

\subsection{Crop rotation on conventional arable and livestock farms in north-east Slovenia}

In the period from 2000 to 2009 crop rotation was reintroduced to conventional arable and livestock farms in north-east part of Slovenia. Before 2003 the maize monoculture was reorganised into two crop production - maize/wheat or maize/barley. A permanent two-crop production - maize/wheat or maize/barley was found in four crop rotations where barley gradually prevailed. The reason for increased production of barley in recent years compared to the past is the stable yield of new 
varieties therefore the production of barley is more economic compared to maize and it has a high fodder quality for domestic animals, mostly pigs. The extreme summer drought in 2003 (Monthly weather report, 2003) was also the reason for sowing the winter barley that ripens before wheat and uses winter moist for growth and development. The crop rotation that included maize and sugar beet was composed entirely of root plants but was too short for sugar beet and therefore inappropriate. By including barley between maize and sugar beet they prolonged the rotation to three years. In that rotation winter rapeseed replaced sugar beet when its production has been abolished in 2008 by the state (the reason was the close-down of the sugar factory in Ormož). On the other side after 2003 the three year root crop rotation (maize - wheat - sugar beet) was shortened to the repeating two-crop production wheat/barley. In nine out of ten crop rotations there are no legumes the only exemption being the rotation on one farm where in 2004 they have decided to sow grassclover mixture (GCM). It remained on the field for two years and afterwards they used the maize-wheat crop rotation. No farm used the supplementary crops that is why the stubbly fields got weedy and became the fertile ground for pests and the need for pesticides increased.

\subsection{Crop rotation on integrated arable and livestock farms in north-east Slovenia}

On integrated arable and livestock farms even before the year 2004 and before farms entered into the supervised production in 2005 they introduced grains into the maize rotation every second and third year and crop rotations with sugar beet lasted three years. With the introduction of the integrated production six farms decided to produce sorghum as the third crop and biotic diversity of otherwise grain crop rotations increased with fodder supplementary crops (Italian rye-grass, Crimson clover, fodder rapeseed) or with supplementary crops for green manure (winter rye); for bee pasture and green manure the farmers sowed California bluebell. After they stopped producing sugar beet four crop rotations used the alternation between maize and wheat or barley and every second or third year they introduced supplementary crops from other botanic families (crucifers, legumes, and water-leaf plants). Annual sowing of Crimson clover as a supplementary crop which is unacceptable due to the auto-toxicity of the Crimson clover has been found in six crop rotations. From the phytosanitary view it would be more appropriate to introduce the alternation between the Crimson clover and fodder rape or other crucifers or to replace the Crimson clover with the Landsberger mixture which beside the Crimson clover also includes vetch and Italian rye-grass. A suitable choice would also be the mixtures of vetch and grains that were often sown on Slovene arable and livestock farms until mid 20th century.

\subsection{Crop rotation on conventional arable and livestock farms in western Slovenia}

Also in the Goriško region (west part of Slovenia) they had to give up successive sowing of maize in 2004. The maize monoculture was supplemented by the grain crops (wheat and barley) in 2004 and 2005.

In phytosanitary terms the rotation of maize and wheat is not suitable since an increased occurrence of fusariosis on wheat can be expected and consequential contamination of food and animal feed with mycotoxins (Bottalico 1998, Bartles in Rodermann 2003, Vanova et. al. 2008, Zemljič et al. 2008,). In phytosanitary terms more suitable rotation would be the oats - wheat rotation that was quite common in the past (Sadar, 1961; Martin et al. 2006).

After 2003 two farms decided to grow lucerne that was left on the field for two or three years which is too short compared to its usual use of four to five years.

From the same reasons as in the Pomurje region, farmers in Goriško region also preferred to grow barley to the wheat.

Six crop rotations used no legumes, and all ten rotations were missing supplementary crops, at least after the harvest of the winter grains. Due to the summer heat and drought in this area there is almost no possibility of supplementary crops on the farms without the irrigation system.

\subsection{Crop rotation on integrated arable and livestock farms in western Slovenia}

On integrated arable and livestock farms in Goriško region (2005-2009) the rotation originates from the maize monoculture or the maize-wheat rotation. Worst phitosanitary effects were detected after two cases of barley crop before the wheat (increased occurence of stub and root rot caused by Gaeumannomyces graminis for wheat) (Cook 2003). After the introduction of integrated production the third crop was introduced into the rotation on all ten farms (spring oats, red clover, fodder sorghum, silage legumes) and the biotic diversity of the rotation was improved by the inclusion of supplementary crops (fodder rape, crimson clover, rapeseed). In six crop rotations we detected successive sowing of Crimson clover.

In phytosanitary sense the break between the crops is also too short in majority of crop rotations that is the 
reason that the pesticides are still used as the basic protection against weeds, pests and diseases.

\subsection{Recommendations of biologically balanced crop rotations}

Alternation between maize and winter grains was the main characteristics of all crop rotations on arable and livestock farms in north-east and in the western region of the country. On integrated farms there is a higher number of crops included in the rotation, but farmers do not always use the correct order and suitable share of individual crops within the rotation.

Compared to presently used rotations on arable and livestock farms with conventional production and with the same number of animals and same type of the livestock production four year rotations are biologically more suitable (Table 1, 2, 3) and producers have a number of options to choose from.

Table 1:Recommended Norfolk four-year crop rotation for arable and livestock farms in north-east and western Slovenia

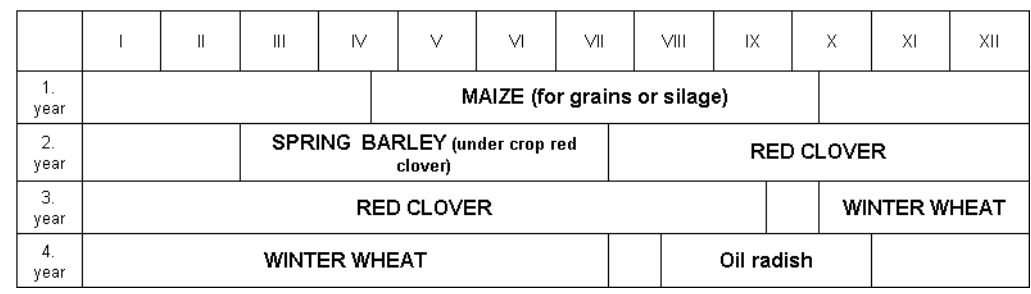

Table 2: Recommendations (a, b, c, d) for a four-year crop rotation in the sequence of leafy plants (L) with cereals (C) (L-C-L-C) for arable and livestock farms in north-east and western Slovenia

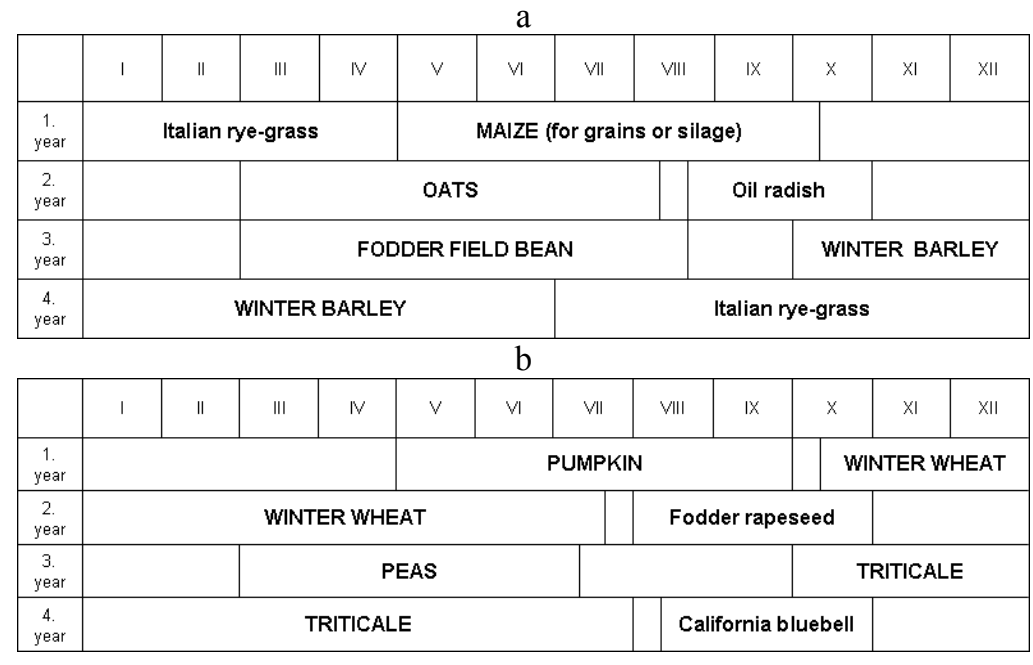

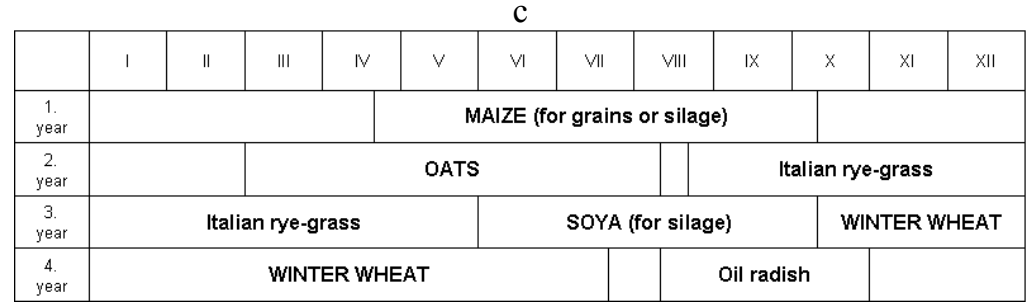

\begin{tabular}{|c|c|c|c|c|c|c|c|c|c|c|c|c|}
\hline & 1 & $\|$ & III & N & v & $\mathrm{vl}$ & $\mathrm{V} \|$ & VIII & $\mathrm{IX}$ & $x$ & $\mathrm{XI}$ & $\mathrm{x} \|$ \\
\hline $\begin{array}{l}1 . \\
\text { year }\end{array}$ & \multicolumn{10}{|c|}{ MAIZE FOR GRAINS } & & \\
\hline 2. & & & \multicolumn{5}{|c|}{ OATS } & & \multicolumn{4}{|c|}{ Landsberg mixture } \\
\hline $\begin{array}{l}3 . \\
\text { year }\end{array}$ & \multicolumn{4}{|c|}{ Landsberg mixture } & \multicolumn{5}{|c|}{ SILAGE MAIZE } & \multicolumn{3}{|c|}{ WINTER WHEAT } \\
\hline $\begin{array}{l}4 . \\
\text { year }\end{array}$ & \multicolumn{6}{|c|}{ WINTER WHEAT } & & \multicolumn{3}{|c|}{ Fodder rapeseed } & & \\
\hline
\end{tabular}


Table 3: Recommendation for a four-year crop rotation in the sequence of leafy plants with cereals (L- L -C -C) for arable and livestock farms in north-east and western Slovenia

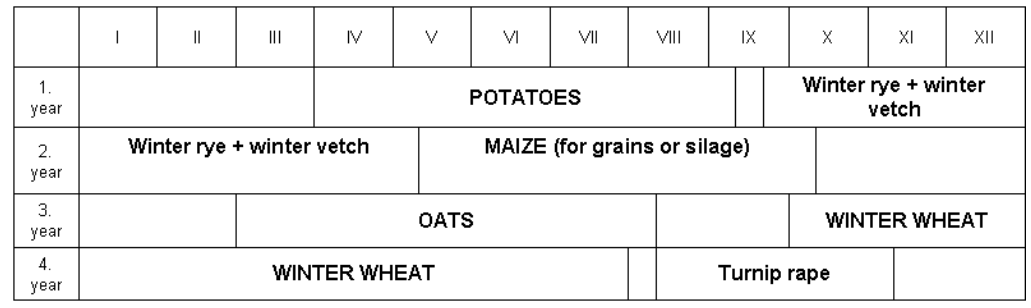

Based on previous practice at home and abroad we have prepared five-year rotations (Table 4 to 6) also for the farms in integrated production. In biotic sense the recommended rotations have much higher biotic diversity than the ones presently used.

Table 4: Recommendation of an old Slovene five-year crop rotation with specific order of leafy plants with cereals: oats-clover-L-C-C for arable and livestock farms in north-east and western Slovenia

\begin{tabular}{|c|c|c|c|c|c|c|c|c|c|c|c|c|}
\hline & 1 & $\|$ & III & IV & $v$ & $\mathrm{~V} \mid$ & $\mathrm{V} \|$ & VIII & $1 X$ & $x$ & $\mathrm{xl}$ & $x \|$ \\
\hline $\begin{array}{c}1 . \\
\text { year }\end{array}$ & & & \multicolumn{5}{|c|}{ OATS (undercrop CGM) } & \multicolumn{5}{|c|}{ CGM } \\
\hline $\begin{array}{c}2 . \\
\text { year }\end{array}$ & \multicolumn{12}{|c|}{ CLOVER-GRASS MIXTURE (CGM) } \\
\hline $\begin{array}{c}3 . \\
\text { year }\end{array}$ & \multicolumn{4}{|c|}{ CGM } & \multicolumn{5}{|c|}{ MAIZE (for silage) } & \multicolumn{3}{|c|}{ WINTER WHEAT } \\
\hline $\begin{array}{l}4 . \\
\text { year }\end{array}$ & \multicolumn{7}{|c|}{ WINTER WHEAT } & & & \multicolumn{3}{|c|}{ WINTER BARLEY } \\
\hline $\begin{array}{l}5 . \\
\text { year }\end{array}$ & \multicolumn{6}{|c|}{ WINTER BARLEY } & \multicolumn{3}{|c|}{ Maize (for silage) } & & & \\
\hline
\end{tabular}

Table 5: Recommendation of an old Slovene five-year crop rotation with specific order of leafy plants with cereals: oats-clover-L-C-L for arable and livestock farms in north-east Slovenia

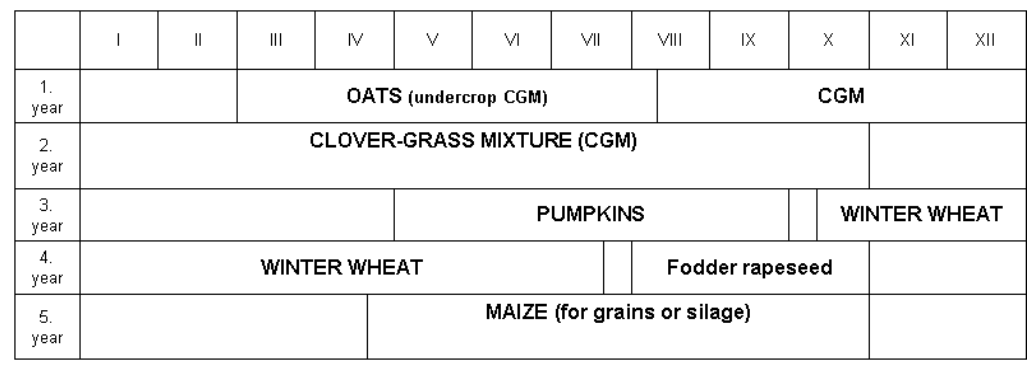

We are aware that in phytosanitary sense the more suitable crop rotations can in short term threaten the intensive livestock production on the farm, but they are acceptable for a long term planned supply of animal feed from natural meadows and pastures from the early spring to late autumn. Higher biotic diversity on arable and livestock farms is therefore limited by the intensity of the livestock production and some breeders and experts strongly oppose such changes. 
Table 6: Recommendations (a, b, c, d) of the Rhyne five-year crop rotation with specific order of leafy plants with cereals: (L-C-C-L-C) for arable and livestock farms in north-east and west Slovenia

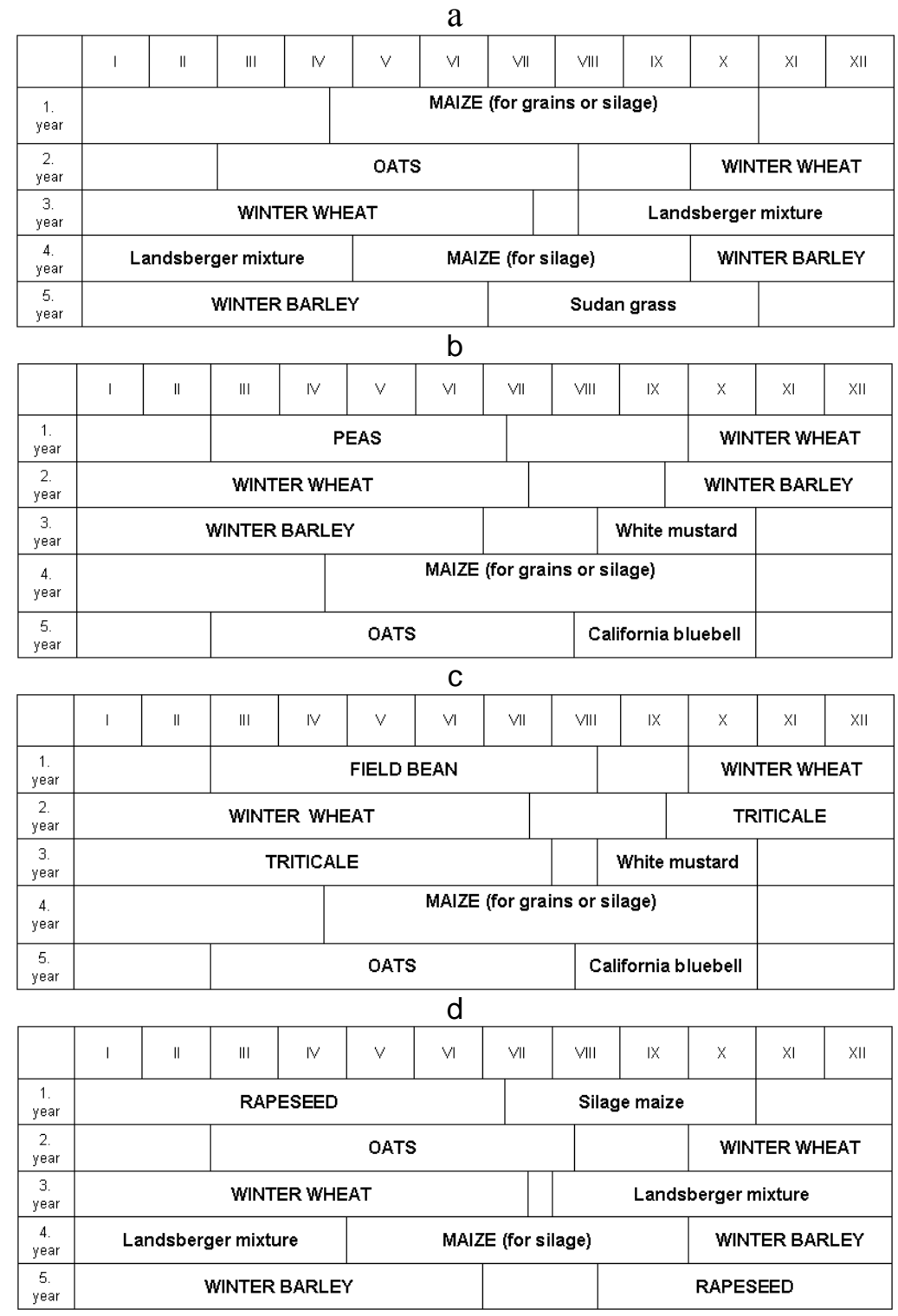

\section{CONCLUSIONS}

These are the findings and conclusions of our analysis of crop rotation on intensive arable and livestock farms:

- The occurrence of the maize beetle in 2003, introduction of the integrated production in 2005 and certain measures of Slovene environmental programme are the main reasons for the reintroduction of crop rotation on Slovene farms.

- Maize is no longer a monoculture, but is still the most frequently produced crop in rotation with wheat or barley.

- In integrated production the third crop in the five-year rotation is most frequently a grain. Biotic diversity, which is essential for healthy crops on integrated farm, is for now depending on supplementary crops, their selection and correct introduction into the rotation.

- While on conventional arable and livestock farms that we have studied in north-east Slovenia there were no legumes in the rotation, on some analyzed farms in Goriška region (west of Slovenia) they have introduced the lucerne into the rotation, which is biologically beneficial only with longer crop rotations, when the break before sowing lucerne for the second time is the same as the number of years that it has been used. 
- The sequence of legumes with shorter growing periods is also problematic. The main reason for that is their auto-toxicity when sown on the same field, therefore we should have a look at mixtures of legumes with grains and grasses that were in a past an important part of crop rotations on arable and livestock farms.

- Introduction of legumes (for fodder and for grains) is also an important possibility to produce proteins on Slovene fields, which also means less expense for protein feed.

- After the production of sugar beet has been abolished on the Slovene farms, there are no real root crops in the rotation. Despite the fact that potatoes and sugar beet are both large users of humus from the soil, as root crops they have a favourable effect and serve as a tampon preventing high weediness.

- We also discovered that farmers only fulfil the minimum legal requirements, included in the Regulation on required procedures and good agricultural practice, Rules on integrated crop production and Rules on the phytosanitary measures to prevent the spreading of the corn beetle.

\section{REFERENCES}

Bartles G., Rodermann B. (2003): Strategien zur Vermeidung von Mykotoxinen im Getreide. Gesunde Pflanzen., 5:125-135.

Bottalico A. (1998): Fusarium diseases of cereals: species complex and related mycotoxin profiles in Europe. J. Plant Path.80:85-103.

Butorac A. (1999): Sustavi biljne proizvodnje. V: Opća agronomija, Školska knjiga, Zagreb: 537-574.

Čergan Z., Jejčič V., Knapič M., Modic Š., Moljk B., Poje T., Simončič A., Sušin J., Urek G., Verbič J., Vrščaj B., Žerjav M. (2008): Koruza. Založba Kmečki glas, Ljubljana: $314 \mathrm{p}$.

Cook R.J. (2003): Take-all of wheat. Physiological and Molecular Plant Pathology, 62: 73-86.

Diepenbrock W., Ellmer F., Leon J. (2005): Ackerbau, Pflanzenbau und Pflanzenzüchtung. Verlag Eugen Ulmer Stuttgart, 366 p. Bodennutzungssysteme: 31-87.

Geisler G. (1980): Pflanzenbau. Paul Parey, Berlin, Hamburg: 268-270.

Kocjan Ačko D., Tolar Š., Šantavec I. (2005): Stročnice v kolobarju slovenskih ekoloških kmetij. Acta agriculturae Slovenica, 85 - 1: 125-134.

Martin J.H., Waldren R.P., Stamp D.L. (2006): Principles of field crop production. Pearson Prentice Hall, Upper Saddle River, New Jersey, Columbus, Ohio: 455-470.

Pravilnik o fitosanitarnih ukrepih za preprečevanje širjenja koruznega hrošča. Ur. 1. RS, Št. 21/2004 in št. 106/2006.
Sadar V. (1961): Poljski kolobar in kolobarjenje. Univerza v Ljubljani, Fakulteta za agronomijo, gozdarstvo in veterinarstvo, $104 \mathrm{p}$.

Spanring J. (1959): Pregled poljščin in predlog nekaterih kolobarjev za Slovenijo: 24 p.

Statistični letopis Republike Slovenije 2008. Ljubljana, Statistični urad RS: 480 p.

Tehnološka navodila za integrirano pridelavo poljščin. 2009. MKGP: 43-49.

Tajnšek A., Šantavec I. (1998): Možnosti za sonaravni poljski kolobar v Sloveniji v primerjavi z državami EU. In: Kmetijstvo in okolje, Bled, 12.- 13. 3. 1998: 223-230.

Vanova M., Klem K., Misa P., Matusinsky P., Hajslova J., Lancova K. (2008): The content of Fusarium mycotoxins, grain yield and quality of winter wheat cultivars under organic and conventional cropping systems. Plant Soil and Environment, 54: 395 - 402.

Vogelsang S., Jenny E., Hecker A., Bänziger I., Forrer H-R. (2009): Fusaria and mycotoxins in wheat - monitoring of harvest samples from growers' fields. Agrarforschung, 16: $238-243$.

Zemljič A., Rutar R., Žerjav M., Verbič, J. (2008): Vpliv sorte, gnojenja $\mathrm{Z}$ dušikom in razkuževanja semen na okuženost zrnja pšenice s Fusarium sp. in onesnaženost $\mathrm{z}$ mikotoksini. In: Novi izzivi v poljedelstvu 2008. Zbornik simpozija, Slovensko agronomsko društvo, Rogaška Slatina: 257-262. (In Slovenian)

Zscheischler J., Estler M., Staudaher W., Gross F., Burgstaller G., Rechmann T. 1990. Handbuch Mais. Umweltgerechter Anbau Wirtschaftliche Verwertung. DLG-Verlag Frankfurt (Main): 251 p. 